Aus den Einsamkeiten Irans. By Alfons Gabriel. pp. $x v$ + 186, 65 illustrations, 2 maps. Stuttgart: Strecker u. Schrader, 1939. RM. 9.

TSOLATED geological observations are recorded in this book 1 which deals with a journey through the Dasht $i$ Lut in Eastern Persia. As data about this region are rare they have been abstracted.

The inner basin of Southern Dasht $i$ Lut is full of wind-eroded ridges of bedded silt rather like loess orientated NNW.-SSE. On the eastern side occurs one of the worlds largest deposits of blown sand. Sand hills rise to about 700 feet above the silty floor. The hills on the eastern side (Lat. $30^{\circ}-31^{\circ} \mathrm{N}$., Long. $60^{\circ}$ E.) yielded boulders of gabbro and grey limestone in the south and of granite with tourmaline-pegmatite in the north, whilst at Chah Ruyi graphitic and sericitic schists outcrop. Granodiorite and epidote-bearing rocks lie to the north with andesites forming ridges in the desert south of Gerri Safid.

The mountains south of the desert along the 28th parallel are mainly volcanic: andesite, dacite and rhyolites predominate, but some olivine basalt also occurs. A dormant recent volcano $\mathrm{Kuh}$ i Bazman, 11,500 feet high, stands in this range with some sulphurous hot springs near its base. Twenty miles south-south-west of it hornblende-granite is exposed which has affected shales on its margin altering them to chiastolite slates. A meteoric crater now 22 feet deep lies about 25 miles north east of the volcano in a region where phyllite occasionally outcrops. An active volcano Kuh i Taftan lies about another 20 miles north east (Lat. $28^{\circ} 40^{\prime}$; Long. $61^{\circ}$ E.) in which dacite, andesite, and their tuffs were collected.

J. V. H.

\title{
CORRESPONDENCE.
}

\section{A SUPPOSED CHELONIAN CARAPACE FROM THE PERMTAN.}

SrR,-In a recent part of the Bulletin of the Geological Society If France (ser. 5, vol. viii, p. 67, 1938), M. F. M. Bergounioux lescribes a supposed Chelonian carapace from the Permian of the Iveyron, and names it Archaeochelys pougeti. Neither in the text, lowever, nor in the accompanying photographs is there any proof If this unexpected discovery. The specimen described seems to ne to be merely a septarian nodule, not a fossil.

A. Smith Woodward. 